\title{
POTENSI PROFESIONAL KESEHATAN DALAM MENJALANKAN INTERPROFESSIONAL COLLABORATION PRACTICE DI RUMAHSAKIT UNIVERSITAS HASANUDDIN
}

\author{
Brajakson Siokal ${ }^{1}$, Wahyuningsih ${ }^{2}$ \\ brajakson.siokal@umi.ac.id \\ wachyouningsih@gamil.com \\ ${ }^{1}$ Bagian Keperawatan Universitas Muslim Indonesia \\ ${ }^{2}$ Bagian Keperawatan Universitas Patria Artha
}

\begin{abstract}
Abstrak
Interprofessional collaboration practice adalah interaksi atau hubungan dari dua atau lebih profesional kesehatan yang bekerja saling bergantung untuk memberikan perawatan untuk pasien, berbagi informasi untuk mengambil keputusan bersama, dan mengetahui waktu yang optimal untuk melakukan kerjasama dalam perawatan pasien. Penelitian ini bertujuan untuk mengetahui potensi profesional kesehatan dalaam menjalan interprofessional collaboration practice di rumah sakit Universitas Hasanuddin. Penelitian ini merupakan penelitian kualitatif dengan desain fenomonologi. Partisipan dalam penelitian sebanyak 7 (tujuh) partisipan yang diperoleh melalui penggunaan teknik purposive sampling. Data dianalisis secara analisis tematik untuk mengetahui tema yang dihasilkan. Hasil penelitian menunjukkan bahwa melalui analisis tematik dihasilkan 4 (empat) tema antara lain: dasar-dasar kompetensi kolaborasi, kriteria keberhasilan interprofessional collaboration practice, hambatan penerapan interprofessional collaboration practice, danharapan profesional kesehatanterhadap interprofessiona collaborationpractice.
\end{abstract}

Kata kunci: Profesional kesehatan, interprofessional collaboration practice

\section{POTENTIAL HEALTH PROFFESIONALS IN APLLYING INTERPROFESSIONAL COLLABORATION PRACTICE AT HASANUDDIN UNIVERSITY HOSPITAL}

\begin{abstract}
Interprofessional collaboration practice is the interaction or relationship of two or more health professionals working interdependent to provide care for patients, work together to sharing information to make decisions together, and determine the optimal time to conduct cooperation in patient care. This study aims to determine the potential of health professionals in carrying running the practice interprofessional collaboration at Hasanuddin University Hospital. This study is a qualitative research design fenomonologi. Participants in the study of 7 (seven) participants obtained through the use of purposive sampling techniques. Data was analyzed by thematic analysis to determine the theme generated. The results showed that through thematic analysis produced 4 (four) themes include: basic competencies of collaboration, success criteria interprofessional collaboration practices, barriers to adoption of interprofessional collaboration practices, and expectations of health professionals to interprofessional collaboration practices.
\end{abstract}

\section{Keywords: Health Professionals, Interprofessional Collaboration Practice}

\section{PENDAHULUAN}

Dewasa ini telah dikembangkan suatu proses atau metode pembelajaran yang bersifat kolaborasi. Metode itu disebut interprofessional collaboration practice (IPCP). Sebelum menjalankan IPCP sebelumnya harus telah diperkenalkan atau dibekali dengan metode Interprofessional Education (IPE). IPE mengarah pada suatu proses dimana 
sekelompok mahasiswa atau profesi kesehatan yang memiliki perbedaan latar belakang profesi berusaha berkolaborasi untuk kesembuhan pasien. Sebelum melakukan interprofessional collaboration practice para mahasiswa tersebut melakukan pembelajaran bersama dalam IPE pada periode tertentu dan berinteraksi serta berkomunikasi dengan baik sebagai tujuan yang utama. Dalam IPE mahasiswa juga berkolaborasi dalam upaya promotif, preventif, kuratif, rehabilitatif, dan jenis pelayanan kesehatan yang lainnya (Fauziah, 2010).

Penelitian yang dilakukan di Jepang pada musibah pasca gempa dan tsunami terhadap implemntasi IPCP dalam melakukan pembelajaran antarprofesi kesehatan cukup efektif dengan sistem IPCP. Keberhasilan tersebut $78 \%$ dapat meningkatkan kolaborasi dan meningkatkan komunikasi antarprofesi kesehatan (Watanabe \& Koizumi, 2010). Di Australia sudah sejak lama dikembangkan IPE bahkan saat ini telah diintegrasikan pada kurikulum pendidikan kesehatan karena $87 \quad \%$ dapat meningkatkan kemampuan kolaborasi, meningkatkan minat mahasiswa kesehatan (Christopherson, 2015).

Negara-negara di Asia pada umumnya masih ada ketimpangan dalam pelayanan kesehatan. Ketimpangan yang dimaksud adalah dominasi dari salah satu profesi kesehatan khususnya profesi dokter. Hal ini sangat jelas terjadi khususnya di negara Indonesia. Profesi dokter masih sangat mendominasi dalam pelayanan kesehatan padahal dalam pemberian pelayanan kesehatan pasien adalah sebagai sentral dalam pemberian pelayanan kesehatan (Fauziah, 2010). Ada profesi dokter, perawat, apoteker, gizi dan lain-lain, semua profesi harus mengedepankan kolaborasi dengan mengesampingkan egoisme dan dominasi dalam pengambilan keputusan kesehatan pasien. Tanpa perawat maka tidak akan terjadi kesembuhan dan perawatan yang baik kepada pasien, begitu dengan profesi dokter, apoteker dan lain-lain. Dalam suatu survei didapatkan data bahwa di Indonesia untuk penerapan kolaborasi pada antarprofesi masih sangat minim yaitu 87 $\%$ belum menerapkan kolaborasi antaraprofesi dengan baik. Profesi dokter masih mendominasi keputusan $96 \%$ pada pelayanan kepada pasien (Nugroho, 2008).

Melalui IPCP diharapkan berbagai profesi kesehatan dapat menumbuhkan kemampuan kolaborasi antarprofesi, dapat merancang hasil dalam pembelajaran yang memberikan kemampuan berkolaborasi, meningkatkan praktik pada masing-masing profesi.

Diharapakan dengan IPCP setiap profesi berperan aktif untuk meningkatkan praktik agar dapat saling melengkapi, membentuk suatu aksi secara bersama. Tujuannya untuk meningkatkan pelayanan dan memicu perubahan; menerapkan analisis kritis untuk berlatih kolaboratif, meningkatkan hasil untuk individu, keluarga dan masyarakat, menanggapi sepenuhnya untuk kebutuhan mereka, mahasiswa dapat berbagi pengalaman dan berkontribusi untuk kemajuan dan saling pengertian dalam belajar antarprofesi dalam menanggapi pertanyaan, di konferensi dan melalui literatur profesional dan antarprofesi (Watanabe \& Koizumi, 2010).

Dengan adanya universitas yang menyelenggarakan beberapa program pendidikan profesi kesehatan akan sering terjadi interaksi dan berkolaborasi antar profesi kesehatan. Inilah yang menjadi salah satu kelebihan untuk pengembangan konsep IPE di Indonesia. Sudah seharusnya trand dan isu mengenai IPE dikembangkan dan ditindak lanjuti dengan serius. Pengaplikasian IPE dapat berupa kuliah pakar dari beberapa latar belakang pendidikan seperti dokter, perawat dan ahli gizi, serta diskusi dalam pemecahan kasus dengan pendekatan dari beberapa aspek kesehatan. pendekatan dua metode ini dalam simulasi program IPE dapat meningkatkan sikap mahasiswa tentang kolaborasi menyelesaikannya. Akan tetapi ada bebrapa kendala dalam menerapakan IPE di Indonesia. Masih banyak praktisi kesehatan yang tidak mengutamakan keselamatan pasien karena beberapa faktor salah satunya adalah lemahnya pengetahuan dan komunikasi diantara praktisi kesehatan (Fauziah, 2010). Mahasiswa juga telah melakukan kolaborasi pada tingkat akademik atau di tingkat sarjana, pada semseter-semester 
akhir, yaitu melalui KKN Profesi atau reguler. Semua mahasiswa KKN yang tergabung merupakan gabungan dari berbagai latar belakang keilmuan yang berbeda-beda.

Selain itu, di Indonesia IPCP perlu pematangan program dan akselerasi seperti negara- negara maju, juga perlu pemerataan dan fokus dalam pengembangannya. Lebih khusus di Rumah Sakit UNHAS dalam hal kolaborasi, sebenarnya telah terjalin, ada kolaborasi perawat dengan perawat dalam membahas suatu kasus kasus tertentu, misalnya kasus diabetes yang dialami oleh pasien. Dokter dan perawat akan berusaha berkolaborasi untuk kesembuhan pasien. Tujuan penelitian ini adalah untuk meneliti potensi profesional kesehatan dalam menjalankan IPCP di Rumah Sakit UNHAS.

\section{METODE}

\section{Lokasi dan Desain Penelitian}

Penelitian ini dilaksanakan di RS Universitas Hasanuddin. Penelitian ini menggunakan jenis penelitian kualitatif dengan pendekatan fenomonologi.

\section{Partisipan Penelitian}

Partisipan dalam penelitian ini adalah perawat dan dokter yang bekerja di RS Universitas Hasanuddin yang berjumlah 7 partisipan. Pengambilan sampel menggunakan metode purposive sampling.

\section{Teknik Pengumpulan Data}

Data primer diperoleh dengan cara wawancara mendalam (in deph interview). Data sekunder diperoleh dari instansi terkait yaitu RS Universitas Hasanuddin.

\section{Analisis dan Penyajian data} tematik.

Analisa data dilakukan dengan analsis

\section{HASIL}

Adapun tema yang dihasilkan dari penelitian ini ada 4 (empat) tema, antara lain : (1) Dasar-dasar kompetensi kolaborasi, (2) Kriteria keberhasilan interprofessional collaboration,

(3) Hambatan interprofessional collaboration, dan (4) Harapan profesional kesehatan terhadap IPC.

Dasar-dasar kompetensi kolaborasi dalam penelitian ini partisipan mengungkapkan bahwa adapun yang menjadi dasar-dasar dari kompetensi kolaborasi yaitu terdiri atas : (a) Terjalin Komunikasi yang baik, (b) Penghargaan dan respek atau saling menghargai, (c) Kepercayaan atau saling percaya, (d) Pengambilan keputusan bersama, (e) Penyelesaian bersama dan manajemen konflik.

Adapun kriteria keberhasilan kolaborasi berdasarkan yang diungkapkan oleh partisipan dalam penelitian ini yaitu : (a) adanya saling percaya dan menghormati, (b) saling memahami dan menerima keilmuan masing-masing, (c) Memiliki citra diri positif, (d) memiliki kemetangan profesional yang setara, (c) Kepercayaan atau saling percaya, (e) mengakui sebagai mitra kerja bukan bawahan, (f) keinginan untuk interaksi atau koordinasi.

Adapun hambatan IPC berdasarkan yang diungkapkan oleh partisipan dalam penelitian ini yaitu : (a) perspektif yang berbeda pada setiap profesi, (b) Sosialisasi IPC yang kurang, (c) SDM yang tidak merata, (d) Kurikulum yang belum terintegrasi.

Adapun harapan profesional kesehatan terhadap IPC berdasarkan yang diungkapkan oleh partisipan dalam penelitian ini yaitu : (a) IPE terintegrasi dalam Kurikulum, (b) Terjalin Komunikasi dan Koordinasi yang baik, (c) Ke depan Penerapan IPC menjadi model dan acuan untuk RS lain.

\section{PEMBAHASAN}

Dalam penelitian ini menunjukan beberapa tema dari hasil penelitian yang ada. Dalam penelitian ini partisipan mengungkapkan bahwa adapun yang menjadi dasar-dasar dari kompetensi kolaborasi yaitu terdiri atas : (a) Terjalin Komunikasi yang baik, (b) Penghargaan dan respek atau saling menghargai, (c) Kepercayaan atau saling percaya, (d) Pengambilan keputusan bersama, (e) Penyelesaian bersama dan manajemen konflik. 
Berdasarkan Christopherson, $\mathrm{T}$. (2015), dalam penelitiannya menyatakan kolaborasi interprofesi meningkatkan efektifitas pelayanan kesehatan dan keselamatan pasien, dengan didasarkan pada beberapa hal terjalin komunikasi dan koordinasi yang baik dan pada saat ada masalah pada pasien, diputuskan secara bersama oleh profesional kesehatan dalam Tim.

Hal ini sesuai dengan apa yang diungkapkan oleh partisipan:

\section{“. .. yah mmm haruski ada komunikasi yang baik sesama tenaga kesehatan sehingga komunikasi itu berjalan efektif..." \\ "....seharusnya dokter dengan perawat kan sudah belajar komunikasi terapeutik"}

Komunikasi sangat dibutuhkan daam berkolaborasi karena kolaborasi membutuhkan pemecahan masalah yang lebih kompleks, dibutuhkan komunikasi efektif yang dapat dimengerti oleh semua anggota tim. Pada dasar kompetensi yang lain, kualitas respek dapat dilihat lebih kearah honor dan harga diri, sedangkan kepercayaan dapat dilihat pada mutu proses dan hasil. Respek dan kepercayaan dapat disampaikan secara verbal maupu non verbal serta dapat dilihat dan dirasakan dalam penerapannya sehari-hari. Feed back dipengaruhi oleh persepsi seseorang, pola hubungan, harga diri, kepercayaan diri, kepercayaan, emosi, lingkunganserta waktu, feed back juga dapat bersifat negatif maupun positif (Thistlethwaite J, 2012). Dalam melakukan kolaborasi juga akan melakukan manajemen konflik, konflik peran umumnya akan muncul dalam proses. Untuk menurunkan konflik maka masing-masing anggota harus memahami peran dan fungsinya, melakukan klarifikasi persepsi dan harapan, mengidentifikasi kompetensi, mengidentifikasi tumpang tindih peran serta melakukan negosiasi peran dan tanggung jawabnya. Kolaborasi akan berjalan dengan baik jika setiap anggota tim saling menghargai dan memahami peran dan tanggung jawab masing-masing profesi, memiliki tujuan yang sama, mengakui keahlian masing-masing profesi, saling bertukar informasi dengan terbuka, memiliki kemampuan untuk mengelola dan melaksanakan tugas baik secara individu maupun bersama kelompok dalam tim (Knowles, 2010).

Adapun kriteria keberhasilan kolaborasi berdasarkan yang diungkapkan oleh partisipan dalam penelitian ini yaitu : (a) adanya saling percaya dan menghormati, (b) saling memahami dan menerima keilmuan masing-masing, (c) Memiliki citra diri positif, (d) memiliki kemetangan profesional yang setara, (c) Kepercayaan atau saling percaya, (e) mengakui sebagai mitra kerja bukan bawahan, (f) keinginan untuk interaksi atau koordinasi.

Berdasarkan TICRCA (2013), kolaborasi adalah bekerja bersama khususnya dalam usaha penggambungkan pemikiran. Hal ini sesuai dengan apa yang dikemukanan oleh Piterman

L. (2010), menggambarkan bahwa kolaborasi sebagai suatu proses berfikir dimana pihak yang terklibat memandang aspek-aspek perbedaan dari suatu masalah serta menemukan solusi dari perbedaan tersebut dan keterbatasan padangan mereka terhadap apa yang dapat dilakukan.

Hal ini sesuai dengan yang diungkapkan oleh partisipan :

". harusnya kan dalam kolaborasi itu
dokter dan perawat merencanakan
dan menentukan bersama tentang
keluhan pasien, terakhir
keputusannya diambil sama-sama,
namanya juga praktek bersama"

Setelah melalui diskusi dan negosiasi yang panjang dalam kesepakatan hubungan professional dokter dan perawat, mendefinisikan istilah kolaborasi sebagai berikut; Kolaborasi adalah proses dimana dokter dan perawat merencanakan dan praktek bersama sebagai kolega, bekerja saling ketergantungan dalam batasanbatasan lingkup praktek mereka dengan berbagi nilai-nilai dan saling mengakui dan menghargai terhadap setiap orang yang berkontribusi untuk merawat individu, keluarga dan masyarakat (Christopherson. T, 2015).

Adapun hambatan IPC berdasarkan yang diungkapkan oleh partisipan dalam penelitian ini yaitu : (a) perspektif yang berbeda pada setiap 
profesi, (b) Sosialisasi IPC yang kurang, (c) SDM yang tidak merata, (d) Kurikulum yang belum terintegrasi.

Hubungan kolaborasi perawat-dokter adalah suatu bentuk hubungan interaksi yang telah cukup lama dikenal ketika memberikan bantuan kepada pasien. Perspektif yang berbeda dalam memandang pasien, dalam praktiknya menyebabkan munculnya hambatanhambatan tehnik dalam melakukan proses kolaborasi. Kendala psikologi keilmuan dan individual, faktor sosial, serta budaya menempatkan kedua profesi ini memunculkan kebutuhan akan upaya kolaborasi yang dapat menjadikan keduanya lebih solid dengan semangat kepentingan pasien. Hambatan kolaborasi perawat dengan dokter sering dijumpai pada tingkat professional dan institusional. Perbedaan status dan kekuasaan tetap menjadi sumber utama ketidaksesuaian yang membatasi pendirian professional dalam aplikasi kolaborasi. Dokter cenderung pria, dari tingkat ekonomi lebih tinggi dan biasanya fisik lebih besar dibandingkan perawat, sehingga iklim dan kondisi sosial masih mendukung dominasi dokter. Inti sesungguhnya dari komplik perawat dengan dokter terletak pada perbedaan sikap profesional mereka terhadap pasien dan cara berkomunikasi diantara keduanya (ACFSAQIHC, 2015).

Hal ini sesuai dengan yang diungkapkan oleh partisipan :

“. .. dokter dan perawat berbeda dalam memberikan pelayanan kesehatan ee tapi tetap saja untuk kesembuhan pasien ..."

“....belum lagi ada koas, residen, spesialis, semua punya ilmu dan tahapan masingmasing ...

Adapun harapan profesional kesehatan terhadap IPC berdasarkan yang diungkapkan oleh partisipan dalam penelitian ini yaitu : (a) IPE terintegrasi dalam kurikulum, (b) Terjalin komunikasi dan koordinasi yang baik, (c) Penerapan IPC menjadi model dan acuan untuk RS lain.

Komunikasi dibutuhkan untuk mewujudkan kolaborasi yang efektif, hal tersebut perlu ditunjang oleh saran komunikasi yang dapat menyatukan data kesehatan pasien secara komperensip sehingga menjadi sumber informasi bagi semua anggota tim dalam pengambilan keputusan. Selain itu perlu penanam nilainilai pada saat akademik, tentang pentingnya IPCP, tujuan dan manfaatnya bahkan perlu dintegrasikan dalam kurikulum pendidikan.

Hal ini sesuai yang diungkapkan oleh partisipan :

“. .. harapan kita ini ada dalam kurikulum karena IPE itu dasarnya... '”

“... sekarang ini kalau tidak salah sudah dimasukkan dalam kurikulum institusi IPE itu..tapi saya kurang tahu

pasti juga, apa memang adami dan startnya kapan ini.

“....itu outputnya pastilah IPE ada dalam kurikulum akademik

\section{KESIMPULAN DAN SARAN}

Potensi untuk menjalan IPC di RS UNHAS terbuka lebar dan bisa diwujudkan. Namun demikian ada beberapa hal yang perlu diperhatikan berdasarkan hasil penelitian ini. Hal ini tergambar pada tema yang dihasilkan. Terdapat 4 (empat) tema yang dihasilkan, antara lain: (1) Dasar- dasar Kompetensi Kolaborasi yang tersusun atas terjalinnya komunikasi yang, adanya penghargaan saling menghargai, adanya saling percaya, didasarkan pada pengambilan keputusan bersama, serta adanya penyelesaian konflik secara bersama, (2) Kriteria Keberhasilan Kolaborasi yang tersusun atas adanya sikap saling percaya, saling memahami dan menerima keilmuan masing- masing, memiliki citra diri positif, memiliki kematangan professional yang setara, mengakui sebagai mitra kerja bukan bawahan, serta adanya keinginan untuk interaksi atau koordinasi, (3) Hambatan IPC yang tersusun atas perspektif yang berbeda pada setiap profesi, sosialisasi IPC yang masih kurang, SDM yang belum merata, serta kurikulum yang belum terintegrasi (4) Harapan Profesional Kesehatan terhadap IPC yang tersusun oleh IPE terintegrasi dalam kurikulum, terjalin komunikasi dan koordinasi yang 
baik serta penerapan IPC menjadi model atau acuan untuk RS lain.

\section{DAFTAR PUSTAKA}

ACFSAQIHC. (2015). National Patient Safety Education Framework. Australia : Springer Christopherson, T. (2015). Informatics-enabled interprofessional education and collaborative practice: A framework-driven approach. Japan : JIEP

Fauziah. (2010). Analisis Gambaran Persepsi dan Kesiapan Mahasiswa Profesi Terhadap Interprofessional Education di tatanan pendidikan klinik. Skripsi S1 Keperawatan Fakultas Kedokteran UGM.

Knowles. (2010). Interprofessional Health Education in Australia the Way Forward. Australia: L- TIPP. Nugroho. (2008).
Pelayanan Kesehatan dengan Sistem Kolaborasi. Jakarta: EGC

Piterman L.

(2010). Interprofessional education for interprofessional practice: Does it make a difference. Australia : Medical Journal of Australia.

Sachiko. M. (2015). The Current Status and Problems with the Implementation of Interprofessional Education in Japan: An Exploratory Study. Japan : JRIPE.

Thistlethwaite J. (2012). Interprofessional education: a review of context, learning and the research agenda. Oxford : Med. Educ.

TICRCA. (2013). Cirriculum Renewal for Interprofessional Education in Health. Sydney: Centre for Research in Learning and Change. 


\section{Lampiran Hasil Analisis Tematik}

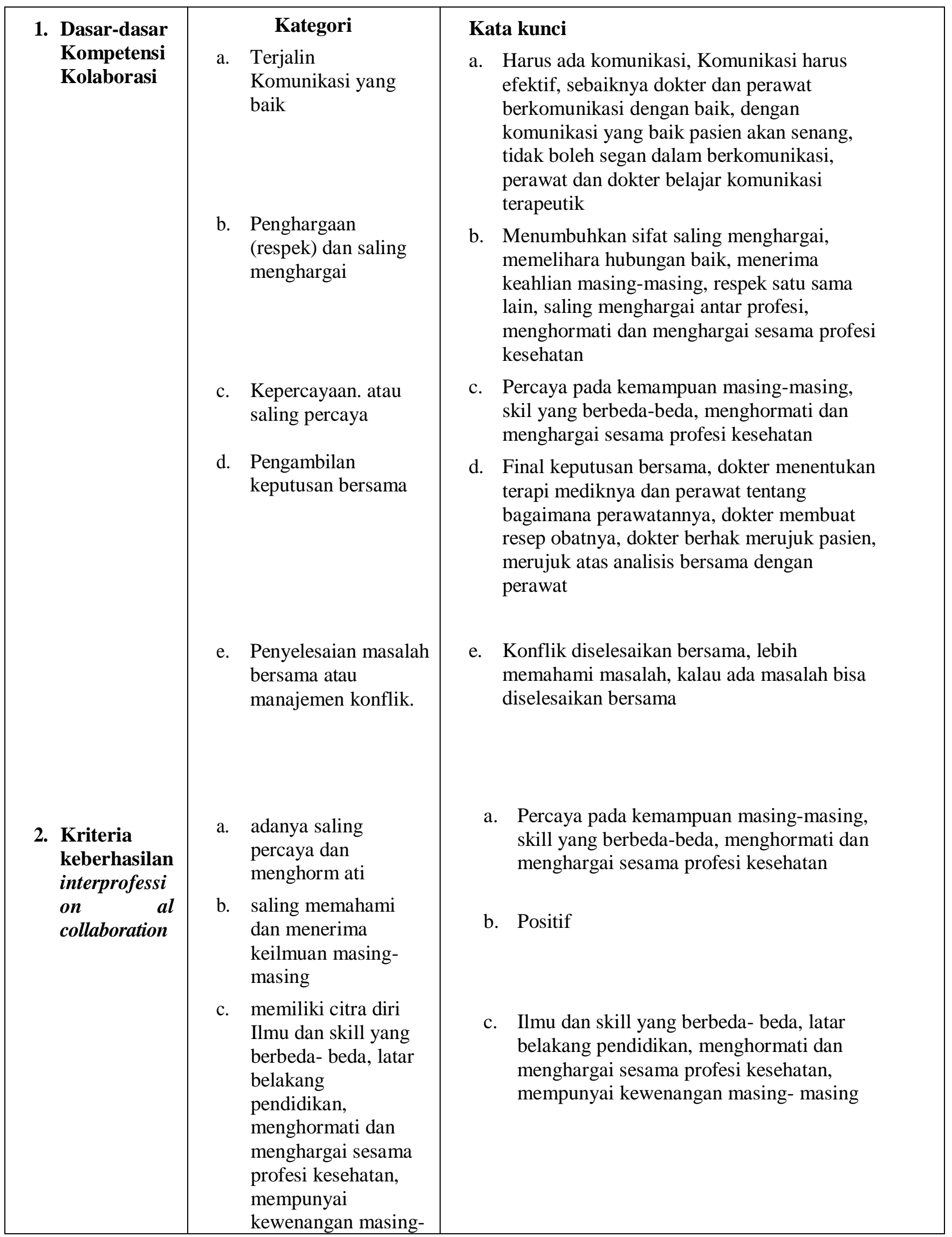




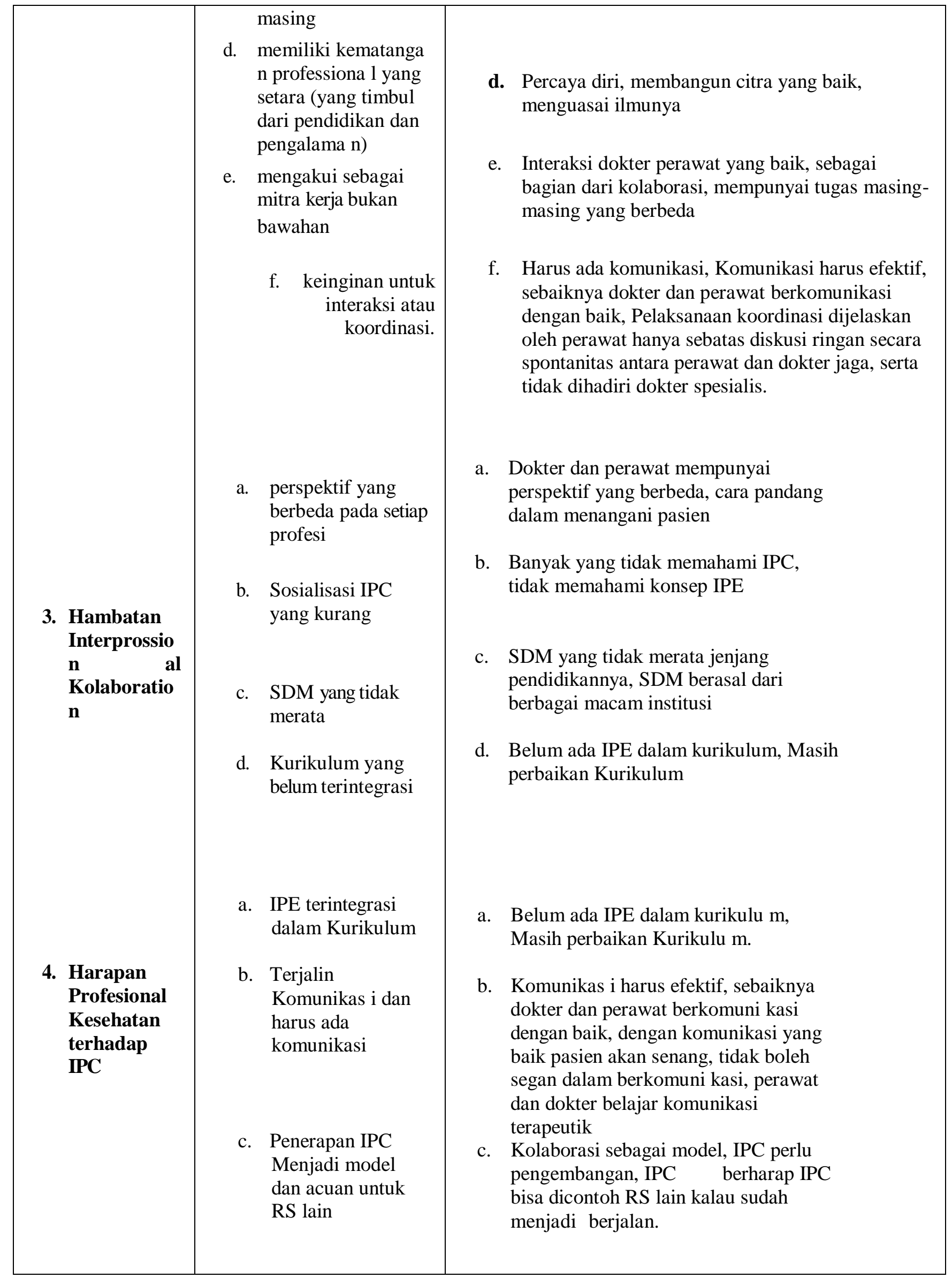

